\title{
Eating patterns and food systems: critical knowledge requirements for policy design and implementation
}

\author{
Hervé Guyomard ${ }^{1 *}$, Béatrice Darcy-Vrillon ${ }^{1}$, Catherine Esnouf ${ }^{1}$, Michèle Marin²$^{2}$, Marie Russel ${ }^{1}$ and Marion Guillou ${ }^{1}$
}

\begin{abstract}
Eating patterns are important for building sustainable food and agricultural systems. This paper begins by presenting the main features of eating patterns worldwide. These eating patterns include the relative convergence of diets, more rapid food transition in emerging and developing countries, development of a more complex food chain, and substantial food losses and waste at distribution and final consumption stages. These patterns have negative consequences on health and the environment. The drivers of these patterns are examined to identify knowledge gaps, the filling of which should facilitate the design and implementation of actions and policies aimed at making food systems more sustainable.
\end{abstract}

Keywords: Eating patterns, Diets, Food losses and waste, Food systems, Food security

\section{Introduction}

According to the 1996 World Food Summit, 'food security at the individual, household, national, regional and global levels is achieved when all people, at all times, have physical and economic access to sufficient, safe and nutritious food to meet their dietary needs and food preferences for an active and healthy life' [1]. The definition broadens the initial focus of the 1974 World Food Summit on the volume and stability of food supplies [2]. It includes secured access to food for all people, especially the most vulnerable, and incorporates food safety and nutritional balance. It also reflects concern about food composition, quality and choice, as well as care related aspects of 'good' nutrition.

Global food is clearly insecure. According to the Food and Agriculture Organization of the United Nations (FAO) [3], 925 million people were undernourished in 2010, and it is now apparent that the target of the Millennium Development Goals of reducing the proportion of people who suffer from hunger by half by 2015 will not be achieved. ${ }^{\text {a }}$ Furthermore, many people are affected by vitamin and mineral deficiencies- one out of three in developing countries according to the World Health

\footnotetext{
* Correspondence: Herve.Guyomard@paris.inra.fr

'INRA Paris, 147 rue de l'université, 75 338, Paris Cedex 07 France Full list of author information is available at the end of the article
}

Organization (WHO) [4]. At the same time, 1.5 billion adults were overweight in 2008, including over 200 million obese men and nearly 300 million obese women [5]. In addition, a growing number of low- and middleincome countries are facing a double burden of malnutrition. That is, these countries exhibit a persistence of under-nutrition, notably among children, along with a rapid increase in numbers of those who are either overweight or obese, as well as those who have diet-related, non-communicable chronic diseases such as cardiovascular diseases and diabetes.

Food security is not just about supply matching demand. The development of agricultural and food systems must take into account the progressive depletion of fossil energy, the protection of soil and water resources, the preservation of biodiversity and the issue of climate change. If they are to feed more than nine billion people by 2050 , farmers around the world will have to produce crops using less fossil fuel in an environmentally friendly way. They will also have to provide energy and industrial commodities in place of petrochemical products, as well as providing environmental and rural services like water management, biodiversity protection, carbon sequestration, or diversified and open landscapes. In addition, food consumption habits will need to adapt. The foresight study Agrimonde [6] clearly shows that by 2050 
eating patterns will be a major issue for world food security. It shows in particular that 'westernized' diets cannot be generalized throughout the planet.

In this paper we will highlight the extent to which eating patterns are important for building sustainable agricultural and food systems, a research and policy area that is too often underestimated in the literature. The focus on the sustainability of eating patterns does not mean that reducing hunger is not a priority. Poverty is the principal cause of hunger, and hunger is a major cause of poverty and under-nutrition [3]. The effect of reducing poverty and hunger, however, is already welldocumented in the literature (see, for example, $[7,8]$ ).

In the first section following the introduction we will present the principal features of eating patterns worldwide. These patterns include the relative convergence of world diets, more rapid food transitions in emerging and in some developing countries, and substantial food waste and losses at distribution and final consumption stages. These common evolutions have negative consequences that will be summarized in a subsequent section. Next, the main drivers of these common eating patterns will be examined in order to make recommendations about knowledge gaps, the filling of which should facilitate the design and implementation of actions and policies aimed at making food systems more sustainable.

\section{Main characteristics of world eating patterns}

Eating patterns worldwide present some common characteristics and evolutions that can be summarized as follows: world diets are converging and the food transition process that began in developed countries is now extending to a growing number of emerging and developing countries at an accelerated rate; the food chain is becoming increasingly complex with food products that are more processed, sophisticated and ready-to-eat; food products are increasingly sold in supermarkets and eaten away from home; food losses and waste are substantial; and a widening gap exists between agricultural production and producers on the one hand and food consumption and consumers on the other hand. This, in turn, is inducing a return by a growing body of consumers to local, natural and traditional agricultural products. The consequences of this "westernization' of world diets, as well as its determinants, will be described in subsequent sections.

\section{World diets are converging}

The food transition process characterizing the convergence of eating patterns includes two main steps. The first one is quantitative. It corresponds to a rise in the calorie intake with proportionally equal increases in all food products. The nutritional structure of this intake is stable. The second step, called 'diet transition', is qualitative. Once caloric saturation is achieved, diet structure changes; consumption of cereals and vegetables decreases while that of sugar, fats and animal products increases. This two-step process is illustrated in Figure 1 for the French case. As in many western European countries, the quantitative phase started with the agricultural and industrial revolutions and developed through the 19th century until sometime around 1910 to 20. From that date, consumption of cereals and potatoes decreased while consumption of fats, oils, sugar, fruit, vegetables and animal products, which was already slightly increasing during the 19th century, grew faster (Figure 1a). Changes in food diet composition translate into changes in macronutrient weight. From 1880 to 1980 the proportion of carbohydrates decreased from 70 to $45 \%$ of the total energy intake, whereas the share of lipids jumped from 16 to $42 \%$; proteins remained constant (Figure 1b).

Developed countries achieved the second step of the food transition process over a century. Many emerging and developing countries in Asia, Central and Latin America, and to a lesser extent in Africa, are now following a similar pattern but at a considerably accelerated rate, as the diet transition is reduced to 20 years in emerging countries and 40 years in developing countries [10]. This is illustrated in Figure 2, which shows that an increasing number of countries are following a similar pattern when one compares the composition of dietary macronutrients among the years 1961 to 1963 (Figure 2a), 2001 to 2003 (Figure 2b) and 2005 to -2007 (Figure 2cc).

In Figure 3 we summarize the food transition process on a two-axis graph illustrating the common trend towards both an increasing calorie intake and a growing share of animal products. As shown in this figure, convergence is not perfect. Diet differences remain between countries for an identical level of economic development, as well as between households within the same country (notably between urban and rural households). These differences are also illustrated in Figure 4 which depicts beef, pork and poultry consumption in several European countries from 1960 to 2003. Although consumption gaps (measured by the ratio of maximal consumption per capita on minimal consumption per capita) are reduced over time, individual meat consumption levels are still significantly different. In the case of beef, consumption levels range from $13 \mathrm{~kg}$ per person per year in Germany to more than $26 \mathrm{~kg}$ in France; in the case of pork, from $28 \mathrm{~kg}$ per person per year in the United Kingdom to $56 \mathrm{~kg}$ in Germany and $62 \mathrm{~kg}$ in Spain; in the case of poultry, from 15 to $16 \mathrm{~kg}$ per person per year in Germany and Italy to 28 to $29 \mathrm{~kg}$ in Spain and the United Kingdom. The gaps in consumption levels of different meats are important not only because of the direct relation between total meat consumption and 
the environment, but also because the animal species have different impacts on the environment, notably in terms of greenhouse gas emissions [11]. A complete analysis of this issue would also require considering the supply and transformation conditions of the different animal productions.

\section{Food products are increasingly processed, sophisticated and ready-to-eat}

The ' 'westernization' of food consumption patterns cannot be characterized simply by the rise in calorie intake; by the increase in sugar, fats and animal products; and by the simultaneous decline in cereals, potatoes and pulses. Food products are also increasingly transformed, sophisticated and ready-to-eat. In 1960, 80\% of French food expenditure corresponded to transformed agricultural products [12]. Since that date, the share is practically stable ( $83 \%$ in 2006) but the nature of the products has changed considerably. Consumption of fresh refrigerated products is 25 times higher today than in the 1960s. Ready-to-eat products began to develop in the 1990s and today represent a significant share of food expenditure. For example, consumption of ready-to-eat products from fish was five times higher in 2000 than in 1960.

In a growing number of countries, unique traditional food habits and ethnic cuisine are increasingly replaced by prepared and ready-to-eat products, soft drinks, supermarket foods and 'westernized' fast foods. In 1945, milk consumption in the United States was four times as high as that of carbonated soft drinks; 50 years later, Americans were drinking 2.5 times as much carbonated beverage as milk [13]. The frequency of eating food prepared outside the home is also well-documented for the United States, where the share grew from $26 \%$ in 1950 to $39 \%$ in 1995 [14]. Supermarkets, along with large-scale food manufacturers, have profoundly transformed agri-food markets in developed countries over the 50 years from 1950 to the beginning of the 2000s [15]. Similar changes have taken place in Central and Latin America in only one decade, from 1990 to 2000; in 2000, the share of supermarkets in the retail business in Mexico and South America (60\%) was four times higher than in 1990 [16]. Since 2000, the movement has been extending to Eastern and Central Europe and to East and South-East Asia, as well as to many urban areas in Africa.

\section{Food losses and waste at distribution and final} consumption stages are substantial in countries where the diet transition has been achieved or is now occurring At the world level less than half of the calories produced by farmers ever make it onto the dinner table (Figure 5). In the early 2000s, farmers globally produced an average of 4,600 kcal per capita per day, including nearly $600 \mathrm{kcal}$ lost at the time of harvesting or lost immediately after harvest. At this stage, the percentages in losses were strikingly
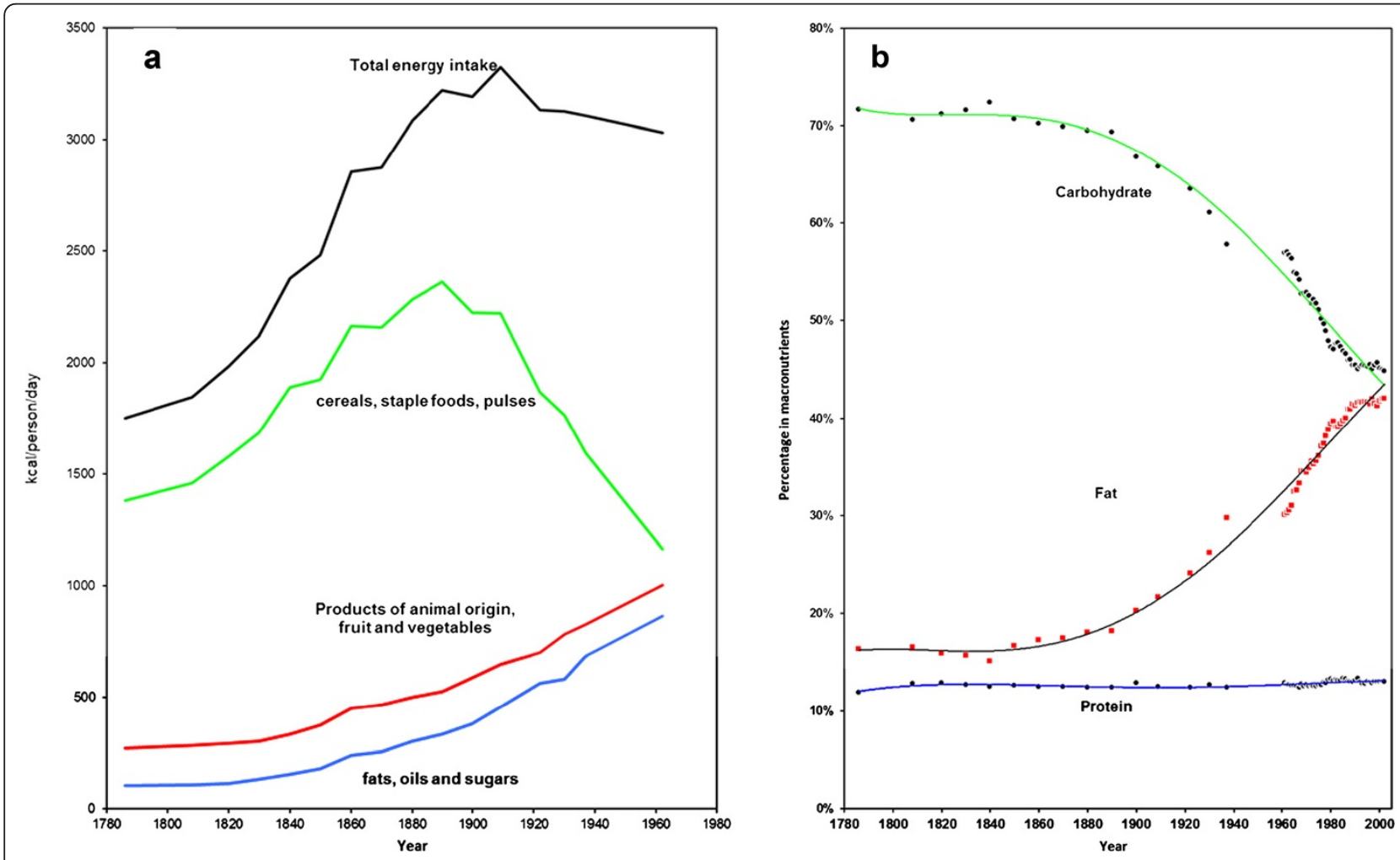

Figure 1 Secular trends in France in (a) the daily calorie intake and in (b) the structure of the diet [9]. 

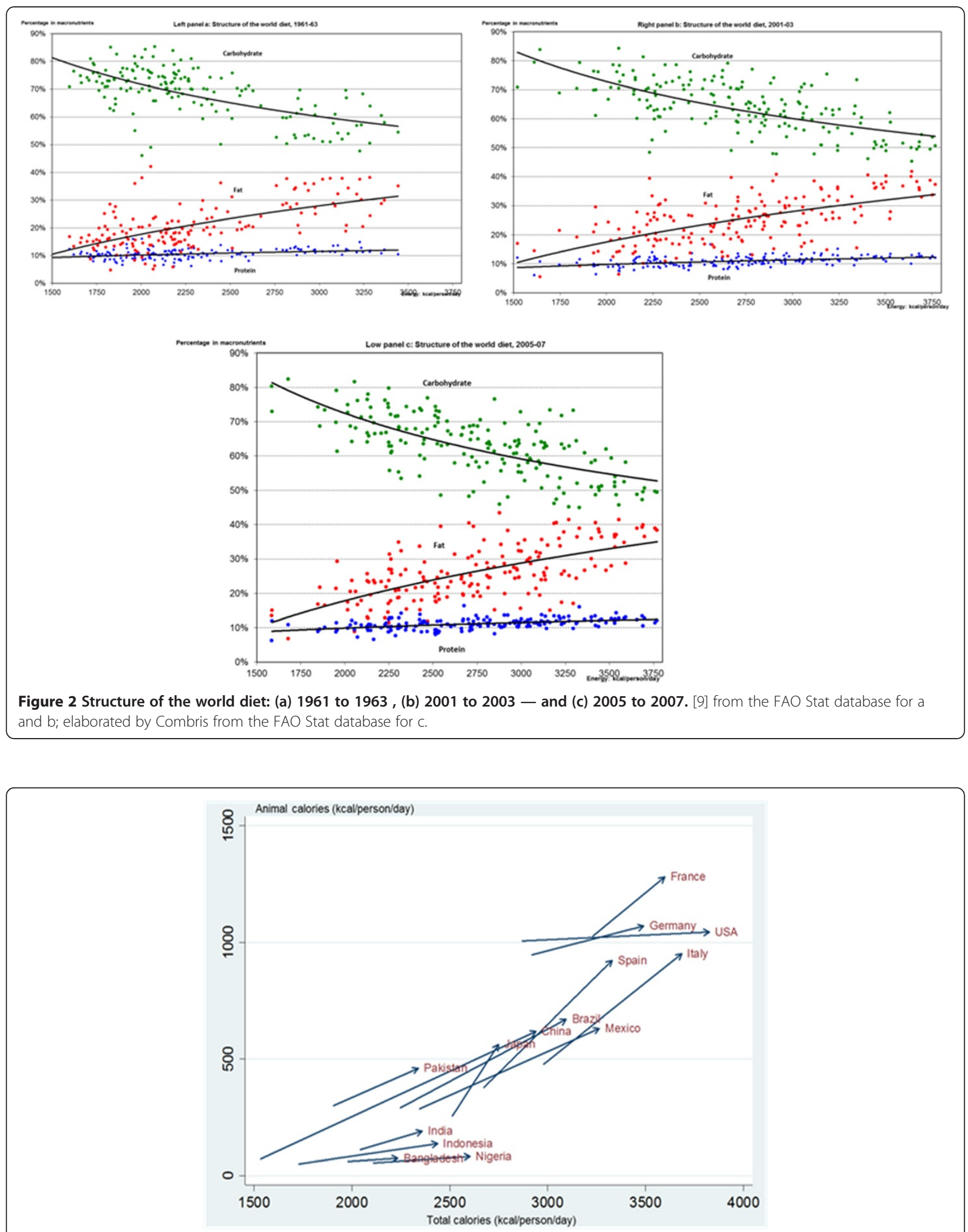

Figure 3 Evolution of total calories and calories from animal products (in kcal/person/day) in various developed, emerging and developing countries, from '1961-63' to '2003-05'. [9] from the FAO Stat database. 


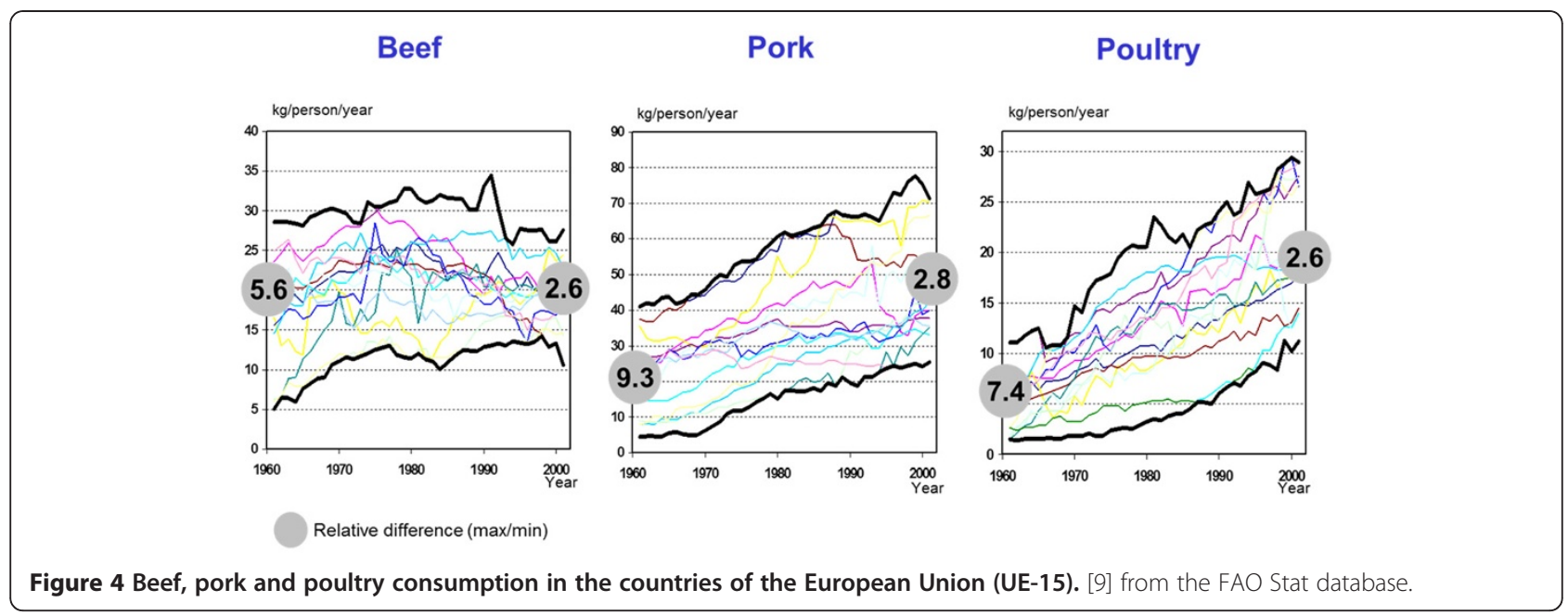

higher in developing countries in comparison to developed nations. The remaining 4,000 kcal were divided between animal feed (1,700 or 43\%) and human food (2,300 or $57 \%)$. The $1,700 \mathrm{kcal}$ used for animal feed produced in return $500 \mathrm{kcal}$ in the form of eggs, dairy products or meat. Of the 2,800 kcal (2,300 from plant products and 500 from animal products) available for human consumption, another $800 \mathrm{kcal}$ were lost during distribution and final consumption. At that stage, the percentages in losses were much higher in countries where the diet transition has occurred or is now occurring than in the developing world. Finally, on average, of the 4,600 kcal produced from plant products for each inhabitant of the world, only 2,000 ended up for actual human consumption $[17,18]$.

These figures show that reducing losses and waste, from field to plate, is a potentially powerful lever that can be used to increase world food availability and define more sustainable food systems and diets. These losses and waste correspond to both market (pecuniary) and non-market (environmental) costs. It is relatively easy to reduce post-harvesting losses through efficient disease control and the development of infrastructure for storage, transport and marketing. At this level, it is essentially a matter of investment and budget. It is much more difficult to reduce losses and waste at distribution and final consumption levels since this requires profound changes in several strongly interconnected aspects such as individual and collective food consumption patterns, food industry behavior and food public regulations. There is a notable shortage of data available on the amount, quality and causes of food waste and losses at the household level. This point-how to reduce food

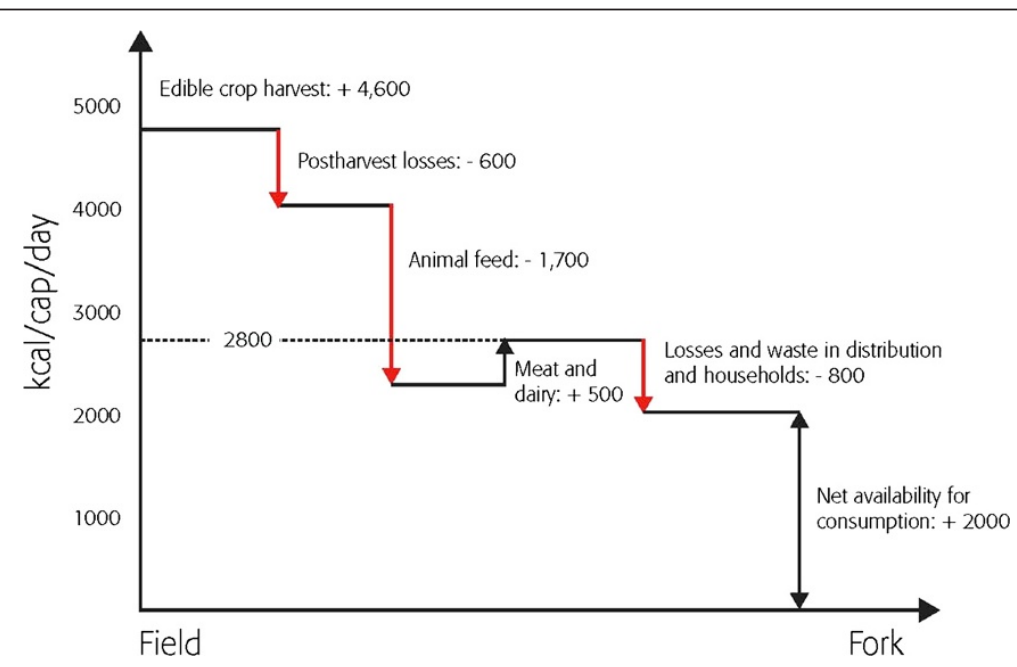

Figure 5 From field to fork: an estimation of food losses, conversion and waste in the world food chain $[17,18]$. 
losses and waste along the whole food chain-will be addressed further in a later section.

\section{The gap between agricultural production and producers on the one hand and food consumption and consumers on the other hand, is widening}

The 'westernized' food system is also based on reducing the range of primary agricultural commodities and achieving specialization for food manufacturers at two stages of the food chain, namely fractioning and formulating, in order to provide consumers with a growing variety of transformed products of regular quality. Traditional consumer skills required for selecting, preparing and storing food products are transferred to the transformation and retail stages of the food chain [19]. Consumers also have to accept that processors and retailers control food safety by conforming to public regulations and standards [20]. They need to quickly acquire new skills to face a rising range of transformed food products. In particular, consumers need to acquire a better understanding of labeling and marketing information.

This evolution toward transformed or processed food generates an increasing 'distance' between consumers and agricultural products. More generally, the gap between agricultural production, products and producers on the one hand and food consumption, products and consumers on the other, covers the three dimensions of technology, space and time [21]. The length of the food chain is growing and food products are more and more sophisticated (technological gap); there is a growing disconnect between production and consumption zones (space gap); and the delay between agricultural harvest and food consumption is extending (time gap). As this three-dimensional gap widens, it makes the final consumer more demanding and anxious about the content and safety of her food [22]. The most concerned households, often well-educated and from a higher economic class, are increasingly seeking answers to this anxiety through new ways of consumption (organic foods, local food systems and so on) that are aimed at reestablishing a link between what they eat and where and how food is produced. This interest by consumers in returning to basic food items that are local, traditional and/or natural could be exploited to improve sustainability, notably through a reduction in energy and transport costs.

\section{Consequences: increasing risks linked to the "westernization' of food patterns}

The 'westernization' of food consumption patterns, as presented earlier in this article, has impacts on the environment and on health. These impacts can be analyzed in terms of risks. Risk management requires action, notably public action. The latter will be efficient if it modifies drivers of undesirable evolutions and changes. These drivers are discussed in the following section.

\section{Impacts on natural resources and the environment}

The 'westernization' of agricultural and food systems has negative impacts on natural resources and the environment. These impacts are well-documented in the literature. Simply put, impacts are related to the so-called intensification of agricultural practices and systems (effects at the intensive margin of production) and the increasing use of land for agriculture (effects at the extensive margin of production). Since the 'westernization' of diets largely determines the evolution of agricultural practices and systems, as well as agricultural land uses, eating patterns clearly contribute to the over-use and degradation of agricultural ecosystems.

Much has been written about the negative impacts of the intensification of agriculture (for food and feed crops, as well as for grass) on natural resources and the environment (soil, water, biodiversity and so on). Modern agriculture has been successful in increasing food production over recent decades but this has led to an environmental cost due to the use of high levels of water, fertilizers and pesticides, along with a reduced number of crop species and varieties being selected. This, in turn, has led to the depletion of aquifers, increased emissions of nitrates and pesticides into the atmosphere and to declining biodiversity (see, for example, [23]).

\section{Biodiversity}

Modern agriculture has a negative impact on biodiversity through three channels: 1) the management of crops to increase their productivity through breeding, fertilizer use and the control of competitors, predators and parasites with pesticides; 2) the transformation of agricultural landscapes into new combinations and arrangements of crops and semi-natural elements; and 3) the transformation of non-agricultural and agricultural habitats [24]. One of the main pressures on biodiversity is the transformation of natural habitats to agriculture, notably through forest clearance [25]. The negative impact of intensification on biodiversity is very well-documented for birds. For example, the large shifts in agricultural management that occurred in England and Wales between 1962 and 1995 provide a plausible explanation for the decline in the farmland bird population observed over that same period [26]. This decline involves many mechanisms, including a reduced food supply for birds, fewer suitable nesting habitats and direct mortality of birds through farming operations.

\section{Greenhouse gas emissions and climate change}

Globally, agriculture, including direct and indirect landuse changes, accounts for one-third of world greenhouse 
gas emissions (Figure 6). Agricultural greenhouse gas emissions (14\%) come from three main sources: 1) nitrous oxide emissions, which are mainly linked to the use of nitrogen fertilizers; 2) methane emissions produced by ruminant animals through the enteric fermentation process or through the anaerobic decomposition of manure; and 3) carbon dioxide emissions from the combustion of fossil fuels. The large rise in the use of nitrogen fertilizers, the number of beef and dairy animals, the number of livestock confinement systems and the agricultural use of fossil fuels have substantially increased agricultural greenhouse gas emissions over the past decades. Land-use change emissions (18\%) result from the conversion of carbon-rich habitats such as forests or permanent grasslands to crop plantations and temporary grasslands for food, feed or fuel. These land-use change emissions, more specifically the indirect ones corresponding to the conversion of crops for producing biofuels that would otherwise be used for food or feed, are at the heart of the very complex debate on the sustainability of biofuels. But the question is not limited to biofuels. It also includes livestock and the rising consumption of animal products as a result of the 'westernization' of diets. Expansion of grazing land for livestock is a key factor in deforestation, especially in the Amazon, where it is estimated that $70 \%$ of previously forested land is now used as pasture, and feed crops represent the main part of the remainder [27]. Globally, FAO estimates livestock production is responsible for $18 \%$ of world greenhouse gas emissions. ${ }^{\mathrm{b}}$
The growing demand for animal products

In addition, as discussed previously, animals are less efficient than crops in transforming solar energy into calories. At a global level, of the 1,700 kcal per person per day used for animal feed, animals return only 500, thus having an animal-product-to-feed conversion factor of 0.29 . Conversion factors vary widely depending on the category of animals ${ }^{\mathrm{c}}$ as well as the production practices and systems used to produce the meat. Globally, poultry and pork production appears more efficient than ruminant animal production.

One essential characteristic of the food transition process is the increasing consumption of animal products, notably meat. Since very few countries can secure the corresponding additional protein demand by grazing, the solution lies in intensifying the cultivation of feed crops (mainly corn and soy), and expanding their cultivated area and/or their importation. As a result, decreasing the global amount of animal production and consumption appears to be a potential lever for increasing global food security and the sustainability of the world agricultural and food system. However caveats exist.

First of all, reducing the consumption of meat products is not advisable on health grounds for many households who lack protein in diets. Furthermore, aging people need a specific protein consumption to combat the age-related decrease in protein metabolism efficiency; such proteins are present in animal products. Secondly, animals, especially ruminants, present several

\section{Global Emissions by Sector}

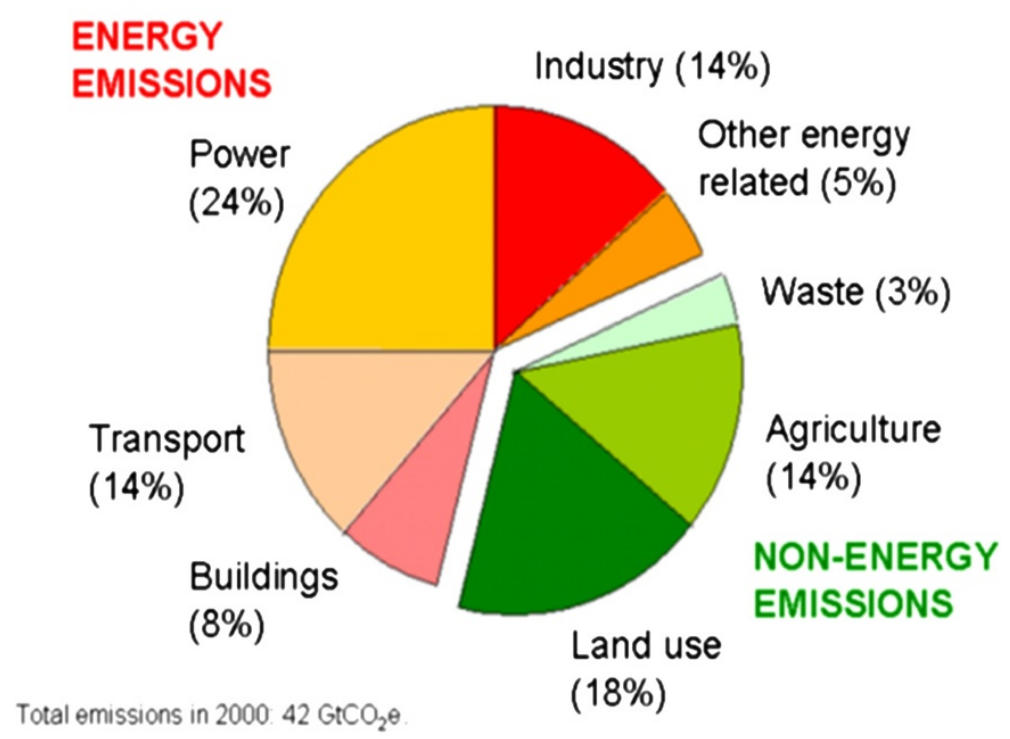

Figure 6 World greenhouse gas emissions by sector [28]. 
advantages from a production point of view. They can exploit large herbaceous areas that would otherwise be unproductive; they provide organic fertilizers and work as draught animals; and they are an important source of income and assets. Finally, the global food equation must be kept in mind, as well as the roles vegetal and animal production play alongside other uses of land.

\section{Impacts on nutrition, health and well-being}

The diet transition summarized earlier in this article can equally be called the nutrition transition, as the changes observed in the nature of the food items consumed result in substantial changes in the percentages of the various macronutrients that compose the energy supply of the diet. The consumption of basic food products (cereals, pulses, starchy foods) declines while that of other food products (sugar, fats, animal products and, to some extent, fruit and vegetables) increases. This translates into a quick increase in the percentage of lipids in the diet-sometimes exceeding $40 \%$ in many developed and emerging countries and households-and a sharp decrease in the percentage of complex carbohydrates, starch and fibers. The total percentage of proteins is more stable, masking a switch from plant to animal sources.

This nutrition transition is associated with changes in lifestyle, such as growing urbanization ${ }^{\mathrm{d}}$, increasing sedentary activities and changing modes of transport, resulting in a switch from high to low physical activity. The conjunction of inadequate situations in terms of nutrition, lifestyle and physical activity has been demonstrated to be associated with increasing risks of weight gain, obesity and diet-related chronic diseases $[29,30]^{\mathrm{e}}$.

An overweight condition or obesity basically results from an imbalance between (increasing) calorie intake and (decreasing) physical expenditure. This is illustrated in Table 1, which shows the simultaneous rise in the calorie intake and the number of overweight and/or obese people in various developed countries between 1980 and 2006. The problem is not specific to high-income countries. Numbers of overweight and obese individuals are dramatically rising in many southern countries in connection to the nutrition transition occurring, especially in urban settings. Emerging countries are the most affected (for example, Brazil, China, and India) but several of the poorest countries of the world are implicated as well, with the exception, at least for the moment, of sub-Saharan African countries. In China, obesity levels among adults are today in excess of 20\%; 90 million individuals are obese and 200 million suffer from being overweight [31]. There are now more overweight and obese people in the world than underweight people [10].

Although there are methodological difficulties and constraints when assessing the long-term consequences of eating patterns on health and population levels, it is now well known and proven that these changes in the diet composition have undesirable health effects, by increasing the risk and prevalence of type 2 diabetes, coronary heart disease, cancer, osteoarthritis, work disability and sleep apnea (see, for example, [33]).

Many low- and middle-income countries are increasingly facing a double burden of under-nutrition (deficiency in energy, micronutrients or both) and infectious diseases on the one hand, and over-nutrition, obesity and degenerative diseases on the other [5]. This double burden is observed not only at the national, but also at the community or household levels. Children in lowand middle-income countries are more vulnerable to inadequate prenatal, infant and young-child nutrition. At the same time, they are exposed to high-fat, high-sugar, high-salt, energy-dense and micronutrient-poor foods, which are often less expensive than healthier foods. These dietary patterns, in conjunction with low levels of physical activity, result in sharp increases in childhood obesity while under-nutrition remains unsolved.

Obesity has a cost for society, both directly and indirectly (because of absenteeism and reduced productivity at work). This point is illustrated for full-time employees in the United States (Figure 7). Medical expenditure and indirect costs due to absenteeism and lower productivity at work rise as the numbers of overweight and obese employees increase.

\section{The relationship between the nutritional value of diets and their environmental impacts can be ambiguous}

As we have previously explained, nutrition transition has negative impacts on both the environment and on health. According to Stehfest et al. [35], a healthier diet would allow world crop areas to be reduced by $10 \%$, and world grassland to be reduced by as much as $10 \%$, with a decrease in mitigation costs of carbon dioxide emissions by $50 \%$ (in 2050 relative to a reference scenario following FAO trend assumptions).

But are things really so simple or, in other words, is it so easy to define eating patterns that are preferable from both an environmental and nutritional point of view? A recent study suggests this might not be the case [36,37]. More specifically, the study concludes that nutritionally adequate self-selected diets may engender higher greenhouse gas emissions than nutritionally inadequate diets. This can occur because nutritionally adequate diets with reduced quantities of animal products are replaced by higher quantities of plant-based products to provide the necessary nutrient intake. This shift can generate high greenhouse gas emissions, perhaps even higher than the nutritional equivalent of animal products. For the same reason, replacing (red) meat with fruit and vegetables is not always the best or most efficient option for reducing the greenhouse gas emissions of diets [38]. In these studies, the most effective 
Table 1 Obese individuals, overweight individuals, and calorie intake in various developed countries, 1980 and 2005/ 2006 [32]

\begin{tabular}{|c|c|c|c|c|c|c|c|}
\hline \multirow[t]{2}{*}{ Country } & \multicolumn{2}{|c|}{$\begin{array}{c}\text { Obesity among adults } \\
\text { (ratio in percent) }\end{array}$} & \multicolumn{2}{|c|}{$\begin{array}{c}\begin{array}{c}\text { Non obese but } \\
\text { overweight adults }\end{array} \\
\text { (ratio in percent) }\end{array}$} & \multirow{2}{*}{ 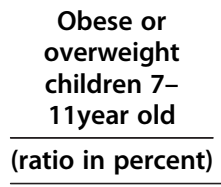 } & \multicolumn{2}{|c|}{$\begin{array}{c}\text { Calorie intake in kcal/day/ } \\
\text { person (in brackets, percent } \\
\text { of fat) }\end{array}$} \\
\hline & & & & & & & \\
\hline Year & 1980 & 2006 & 1980 & 2006 & 2000 & 1980 & 2005 \\
\hline Australia & 8.3 & 18.7 & 28.0 & 34.4 & 26.2 & $3,051(33 \%)$ & $3,084(39.1 \%)$ \\
\hline Canada & 13.8 & 23.1 & 35.4 & 36.1 & 25.1 & $2,946(37 \%)$ & $3,552(37.1 \%)$ \\
\hline France & 6.5 & 11.5 & 26.9 & 31.5 & 19.0 & $3,376(39 \%)$ & $3,603(40.7 \%)$ \\
\hline Germany & na & 13.6 & na & 36.0 & 16.0 & $3,338(37 \%)$ & $3,510(35.9 \%)$ \\
\hline Greece & na & 16.4 & na & 41.3 & 31.0 & $3,216(35 \%)$ & $3,700(35.7 \%)$ \\
\hline Italy & 7.1 & 10.2 & 27.4 & 35.0 & 36.0 & $3,589(32 \%)$ & $3,685(38.4 \%)$ \\
\hline Japan & 2.0 & 3.4 & 15.6 & 21.8 & 17.8 & $2,720(23 \%)$ & $2,743(28.0 \%)$ \\
\hline Netherlands & 5.1 & 11.3 & 28.2 & 35.2 & 12.0 & $3,071(38 \%)$ & $3,240(38.2 \%)$ \\
\hline Norway & na & 9.0 & na & 34.0 & 18.5 & $3,350(40 \%)$ & $3,478(37.4 \%)$ \\
\hline Great Britain & 7,0 & 24.0 & 29.0 & 38.0 & 20.0 & 3,159 (39\%) & $3,421(36.5 \%)$ \\
\hline USA & 15.0 & 34.3 & 32.4 & 33.0 & 15.2 & $3,155(36 \%)$ & 3,855 (39.4\%) \\
\hline
\end{tabular}

way of associating health and environment benefits appears to be a reduction in food quantities consumed.

\section{Drivers of eating patterns}

Food consumption depends on a large and complex set of factors related to food availability, accessibility and choice
[13]. In this section, we review the various determinants that shape the nutrition transition process. Some of these determinants are specific to individuals and others depend on their environment. Some are physiological while others are linked to food characteristics, or are rooted in social interactions and cultural backgrounds. Furthermore, food

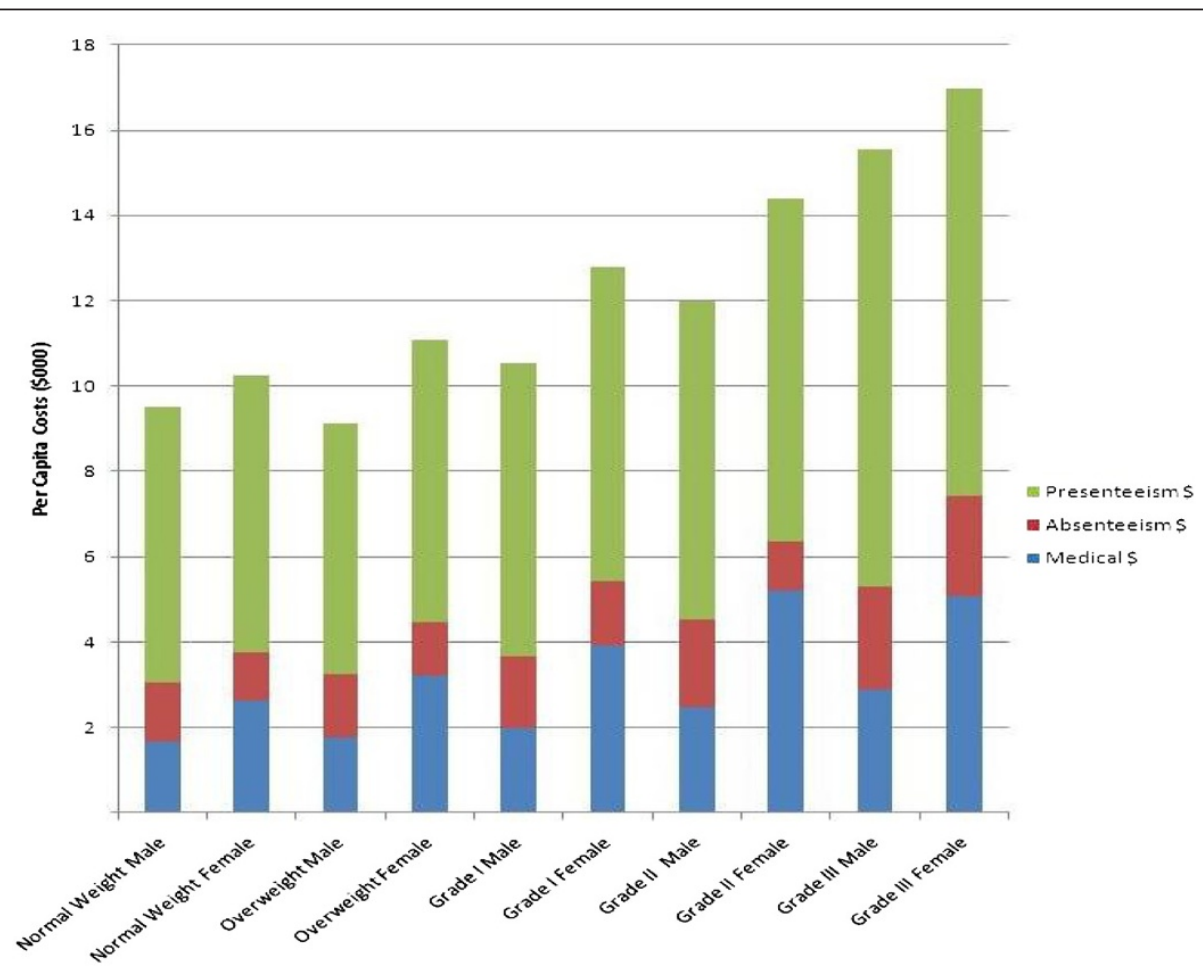

Figure 7 Direct (medical) and indirect costs due to overweight and obesity in the United States [34]. 
behavior is under the complex influence of a large range of short-, medium- and long-term regulation policies that involve these different drivers. Attention is focused on the underlying mechanisms of these drivers and their relative importance in order to pinpoint levers that could be used to limit deregulation sources and favor sustainable regulation pathways. An overall approach to food and diet patterns is required.

\section{Physiological factors \\ Nutritional requirements}

The primary reason for eating is the necessity for each individual to meet his or her nutritional needs. Energy and specific nutrients are needed for body maintenance, as well as specific functions such as growth, pregnancy or lactation. Except during infancy where maternal milk can cover all nutritional requirements, eating a combination of different food products is necessary to ensure an adequate supply of all needed nutrients. There is an almost infinite variety of food combinations that can define an adequate diet from a nutritional standpoint. This is an important consideration both from a cultural perspective and when considering food-based dietary guideline development.

Whereas biological events accounting for nutritional needs, such as cell and tissue metabolism, take place continuously over time, food intake is discontinuous in time and is organized around a few eating occasions on a daily basis.

\section{Short- and long-term regulation of food consumption and metabolism}

Food intake has a circadian variation, with food being ingested during activity periods (daytime for human) and fasting during the remaining time (rest and sleep periods). During the feeding period, food intake is discontinuous for most species. In the case of animals, the lag-time between two intake periods is a major factor of energy intake control. In the specific case of humans, the pace of feeding episodes is influenced by a complex range of social references that define the number and content of food intakes (that is, meals).

Each eating occasion is composed of three components: the pre-ingestive phase where hunger can be experienced is followed by a prandial phase during which food is ingested, leading progressively to a feeling of satiation, and then to a post-prandial phase of variable duration corresponding to satiety.

Overall food intake is controlled by both the quantity of food ingested during eating episodes (involving the satiation process) and the time elapsed since the last eating episode (involving satiety controlled on a short-term basis). It also depends on food availability, which represents an environmental (external) control mechanism.
The main mechanisms controlling food intake are increasingly well-known and understood. These mechanisms include brain structures, mainly located in the hypothalamus [39], and regulation through signals, both short- and long-term [40]. Short-term signals are sensory and digestive and are thus directly linked to food intake. The nutritional composition and consistency of food determine the satiation capacity. The long-term regulation process involves hormonal signals, primarily from leptin and ghrelin [41]. The intensity of these signals is linked to adipose tissue mass with a delayed action as compared to the time of eating.

\section{Food intake control by physiological mechanisms is disrupted by immediate environmental factors}

The whole set of regulation mechanisms described above allows self-regulation of energy intake, being particularly effective in young children in 'normal' situations [42]. This is not the case in obese people where this regulatory system seems to be altered [43].

Energy compensation can take place between two successive meals in case of temporary deficiency or excess. But dietary deficiencies are compensated far more easily than excess is managed. In a society of food abundance and choice, temporary overeating is thus more likely to be poorly managed during subsequent meals, leading to excessive weight gain and obesity.

Food intake is adjusted more effectively by eaters who are 'listening' to the physiological signals of hunger or repletion and pay more attention to what they eat. Distractions (such as eating in front of the television or in a noisy place) increase the quantity ingested during the meal and upset the energy compensation process from one meal to the next [44].

Eating triggers a sensation of enjoyment by activating a physiological system in the brain called the reward circuit. Eating enjoyment is accentuated by palatable foods, which are often fatty or sweet, high energy-dense food items. A propensity for sweet foods has been observed from birth. In obese animals and humans, recent findings have shown that addictive-type mechanisms can develop for sweet foods.

Social norms and attitudes, which vary according to age group, personal experience, social and cultural background, can shape and set dietary behavior, particularly those behaviors associated with time schedules, family meals and table manners. These social conventions also affect the physiological regulation mechanisms [45].

\section{Economic factors}

Food prices, more or less influenced by policies, notably agricultural policies, play an essential role

The industrial revolution (18th and 19th centuries) and then the agricultural green revolution have allowed world 
agricultural and food prices to decrease in real (deflated) terms over several decades. Over the past 50 years or more, the supply of most agricultural and food commodities has grown faster than the demand in spite of an increasing population. As a result, the real prices of agricultural and food commodities have exhibited a downward trend. This is illustrated in Figure 8, which depicts United States price indexes for maize, wheat and soybeans from 1924 to 2008 , expressed in real terms by deflating with the index of prices paid by farmers [46].

This declining price trend has contributed to the alleviation of hunger in the world in relative terms (from more than $30 \%$ in the 1970 s to slightly more than $15 \%$ today) and also in absolute numbers over the three decades from 1970 to 2000 . This does not apply to the years since 2000, especially during the 2008 food crisis and the 2009 financial crisis. This declining price trend has also contributed to easing the nutrition transition and accelerating it in non-developed countries.

Impact of food prices on eating patterns Relative prices of agricultural and food prices can also influence the diet composition by favoring food items that are unhealthy from a nutritional point of view or, on the contrary, disadvantaging them. According to Beydoun et al. [47], 'food [relative] prices are associated with dietary quality, fast-food consumption and body mass index among US children and adolescents. ${ }^{f}$ More specifically, this study shows that lower prices of fruit and vegetables are associated with greater fiber consumption and reduced body mass index and higher fast-food prices are associated with lower consumption of fast foods and higher consumption of dietary fibers, dairy products, calcium and fruit and vegetables. As a result, modifying relative prices of unhealthy versus healthy foods appears to be a lever than can be used to improve dietary quality. From that perspective, more and more voices are raising the issue of a potential connection between agricultural policy and overweight and obese populations. Agricultural policy can keep artificially low the relative prices of cereals, oilseeds and sugar crops, as well as the prices of processed food ingredients and animal products that use these crops as feed inputs, and artificially high the relative prices of less dense foods such as fruit and vegetables [48]. For example, Schnoover and Muller [49] argue that in the United States, there is a direct relation between declining real prices for corn and soy, increasing use of fats and oils in processed food products, and the rise in obesity. Similarly, Lloyd-Williams et al. [50] conclude that the Common Agricultural Policy of the European Union has led to a significant increase in mortalities attributable to cardiovascular events by favoring the consumption of saturated fats.

Assessing the impact of agricultural policy on eating patterns There is however a strong debate about the health effects of agricultural policy and whether new pricing and/or subsidizing rules in the agricultural sector could help individuals adopt better eating habits. Furthermore, as noted by Mazzochi et al. [51], new pricing and/or subsidizing or taxing policies, while discussed regularly, are rarely enforced.

Price support policies and import trade barriers used, for example, in the European Union and the United States have a positive impact on the domestic prices of commodities supported or protected in this way and thus reduce their consumption, ceteris paribus. In contrast, coupled production subsidies tend to reduce domestic prices (because they incite farmers to produce more but have no direct impact on agricultural prices) and thus increase the consumption of products

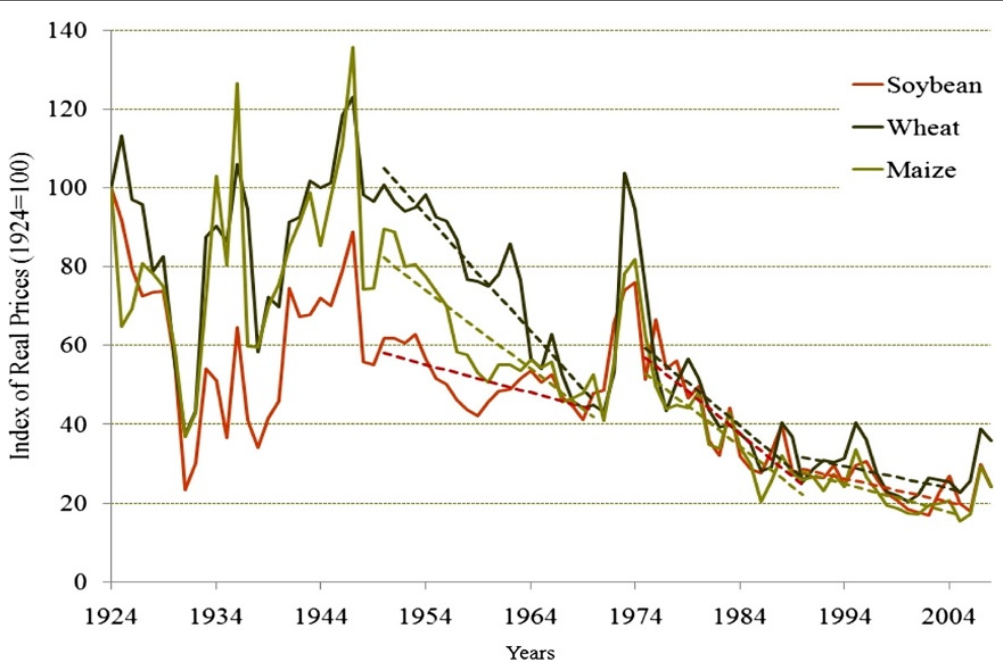

Figure 8 United States: real prices of maize, wheat and soybeans [46]. 
supported in this way, ceteris paribus again. Suppressing the whole set of agricultural policy instruments used in a given country, therefore, may have an ambiguous effect on the caloric content of diets and diet composition, depending on the relative importance of each instrument and how each agricultural product is supported or protected. This is confirmed by the work of Alston et al. who show that eliminating all United States agricultural policies would have only a modest impact on annual calorie consumption in that country [52]; more specifically, they claim that eliminating grain subsidies would decrease annual caloric consumption by less than 1,000 calories for each American adult whereas eliminating both grain subsidies and trade barriers would increase this annual caloric consumption by around 200 calories for each American adult.

However, this does not mean that the lever of agricultural policy is neither relevant nor efficient for improving diets. The problem is not with production subsidies, trade barriers or consumption taxes per se. It is rather with the disconnect between the current forms of farm programs as they are applied in a vast majority of countries and the long-term policies that should be set up to promote healthier diets and more generally, the sustainable development of agricultural and food systems, from field to fork. In other words, the problem is with the inconsistency of current (agricultural) policy, which very often neglects spillover effects. This can be illustrated by the work of Bonnet and Réquillart who analyze the impact of the European sugar reform on the consumption of sugar sweetener beverages in the European Union [53]. The reform mainly consists of a significant decrease in the domestic price of sugar. It is aimed at gaining consistency (between policy instruments used in the sugar sector and in other agricultural sectors) and compatibility with World Trade Organization rules. But in doing so, the reform is at odds with what is recommended by nutritionists and public health authorities. Specifically, the reform would raise the French consumption of regular soft drinks by more than one liter per person per year and the consumption of added sugar by $124 \mathrm{~g}$ per person per year. Furthermore, the substitution game between brands would favor products with the highest sugar content and the rise in consumption levels would be more significant in overweight and obese households.

\section{Household income is a key determinant of eating patterns}

It is now well established that rising household incomes lead to more unhealthy diets by favoring an increased consumption of fats, oils, sugar, animal-based products and processed foods [54].

Of course, this direct causality should not invite us to blame an increase of individual incomes. As noted by Kearney [13] quoting Marmot [55], 'in most industrial countries (for example, the United States or the United Kingdom), the effects of increased income have generally been considered as beneficial, resulting in better quality diets, better healthcare, lower morbidity and mortality from infectious diseases and lower risk of obesity.' In developed countries where the nutritional transition is achieved and in emerging or developing countries where it is occurring, the conventional wisdom is that the poorest families have the worst diets from a nutritional standpoint. This is mainly because lower-income people have less access in their immediate neighborhood to affordable healthy foods like fruit and vegetables that are relatively more expensive than high-calorie foods. Relative to richer and more-educated households that can largely choose their lifestyle, poorer and less-educated families have fewer food choices. This shows that even if income is a key parameter, it cannot and should not be analyzed independently of the whole set of food consumption drivers. These include food prices but also include many individual variables such as socio-economic status, culture or religion, as well as environmental or global determinants such as urbanization, globalization and marketing.

This means that a systemic approach to food consumption behaviors is required; otherwise one risks coming to erroneous conclusions and making inefficient policy recommendations. This point can be illustrated by noting that children from British families with an annual income of between $£ 22,000$ and $£ 33,000$ are $10 \%$ more likely to be overweight or obese than those from families with an income of less than $£ 11,000$ [56]. This is mainly because of the rise of highly paid working mothers in the first group of families who are then forced to leave a nanny, child minder or someone else in charge of their children's diet and physical exercise. The authors of this study conclude that 'long hours of maternal employment, rather than lack of money, may impede young children's access to healthy foods and physical activity. Policies supporting work-life balance may help parents to reduce potential barriers.'

\section{Other drivers: urbanization, food retailing and industry, marketing and advertising, food environment, sociology and culture}

Urbanization Historically, urbanization is strongly related to industrial and agricultural revolutions. A decline in physical activity results in lower energy needs, while at the same time working ability, life span and life quality increase. Today the challenge consists of feeding an increasingly urbanized world population and a growing number of very large megacities (especially in emerging and developing countries) in a sustainable way, while improving the situation of farming and rural 
households that still represent the bulk of poor and hungry people. The more a society is urbanized, the more it challenges the sustainability of its agricultural and food system, mainly in terms of transport, supply chain and modified diets.

The influence of urbanization on eating patterns is partly linked to the distance between consumers and the various supply sources (shops, restaurants, dispensers, et cetera) [57]. In developed countries, the numbers of supply sources, their relative importance, and their repartition have undergone important changes in the last 50 years. In the United States, for example, the increasing concentration of fast-food restaurants accounts for the frequency of overweight and obese individuals [58]. Evolutions are today similar and faster in a growing number of emerging and developing countries.

\section{Food retailing and industry}

In most developed countries, the food supply has gone from specialized shops to larger and non-specialized supermarkets and shopping malls. In a country like France it took 40 years for this change to occur. Although supermarkets and shopping malls were only 5\% of the total food expenditure in the 1970s, they now represent $70 \%$. A similar evolution is occurring in many emerging and developing countries where uniform and centralized supermarkets and shopping malls are increasingly and quickly replacing small shops. The movement starts from basic foods like corn, oil or sugar, and extends to fresh ones. In emerging and developing countries, supermarkets and shopping malls are no longer the domain of the richer households of capital cities. They are now consumption places for urban crowds with increasingly 'westernized' lifestyles [16].

The worldwide rise in supermarkets and shopping malls comes with the development of transnational food corporations (franchises and manufacturers) like Danone, Nestlé or McDonalds. These transnational food corporations are significant drivers of the nutritional transition and the 'westernization' of food consumption behaviors [59]. The 'fast-food cultural infiltration' means that fast-food restaurants can now very easily be found in shopping malls, railway stations, airports, and schools. In highly populated communities, you can drive just a few kilometers and pass several fast-food restaurants and convenience stores. The increase in numbers of these stores comes with the development and concentration of brand names that have changed the relationship between consumers and producers and led to changes in profit sharing to the detriment of agricultural producers.

\section{Declining physical activity and growing food marketing}

Many activities now widely undertaken by adults and children involve very little physical activity. In a growing number of cultures, the most popular leisure activities, especially for children and teenagers, are watching television or videos, playing electronic or computer games, and surfing the internet. These passive forms of entertainment are replacing more traditional and more physical recreational activities. This ever-increasing sedentary lifestyle is accompanied by growing marketing and advertising expenditures from both transnational food corporations and supermarkets. These are essential factors for the 'westernization' of diets. According to Willett [60], exposure to TV advertising might even be the single largest determinant of child obesity in the United States.

\section{Food environment, sociology and culture}

People make decisions based on their food environment, community, family, culture, and history. All these miscellaneous factors influence food consumption behaviors and habits in a way that may or may not be favorable to more healthy diets. It is, for example, particularly important to create food environments that make it easier for individuals and families to choose healthy diets and engage in physical activity. This is more likely to happen when one is provided with food options that are low in calories, fats and added sugar, and that are rich in fruit and vegetables. In France, the convergence of eating patterns meets resistance from familial and cultural habits. In 1997, four out of five French people were having lunch at home on weekdays, a percentage increasing to $90 \%$ for dinner [61]. Recent observations suggest that the first percentage is slightly decreasing while the second remains constant. Today $75 \%$ of French people have lunch at home but with considerable variation according to age, location and socio-economic status.

A common wisdom is that traditional meals are losing ground in France. Such an assertion is quite difficult to prove and feeds a controversy around 'the breakdown of the French meal pattern'. Sociology research shows that many factors interact around the French meal pattern, such as deregulation of family life, more individualized lifestyles and more independent teenagers [62]. Such evolutions could foster more individualized food intakes as illustrated by meal-trays used in front of the television, in sitting rooms or even with guests.

Despite the global convergence of eating patterns, several types of behaviors co-exist inside one pattern. Nutritional implications of such disparities are expressed through social differences in terms of health. Many diet-related diseases affect lower social categories more frequently and social inequalities in health are growing [63-66].

To reduce those inequalities, the study of main consumption trends should take account of various balances depending on life standards. Thus, in France, the relative 
shares of animal and vegetal foodstuffs are known to vary according to income, education level and socio-economic status. For example, the consumption of animal foodstuffs is lower in upper social categories $[67,68]$. Similarly, nutritional messages are known to have different impacts depending on education level and social background of the person receiving the message [69].

\section{Achieving greater sustainability of food systems through healthier eating patterns: knowledge gaps and action recommendations}

As highlighted by the foresight exercise Agrimonde [6], defining healthier and environmentally friendly diets would require changing behaviors along the whole supply chain, from consumption habits to agricultural practices and systems. Apart from the adjustment of quantities consumed in relation to a better nutritional balance of diets, reducing losses and waste along the whole food chain and saving fossil and natural resources are major targets.

\section{Reducing food losses and waste along the whole food chain}

The FAO estimates that achieving global quantitative food security by 2050 would require an increase in world agricultural production by as much as 70\% [3]. As established in the recent United Kingdom foresight exercise on food and farming [70], halving losses and waste along the food chain represents an economy of $25 \%$ of current agricultural production. Other estimates are even more optimistic. Harvest and post-harvest losses (primary losses) are much more important in the developing world, while losses at distribution and final consumption stages (secondary losses) are greater in developed countries, especially those countries that have experienced or are experiencing the food transition.

Factors for secondary food losses are multiple and involve a large set of complex mechanisms. These mechanisms depend on exogenous factors (for example, climate and safety) as well as human factors, including management practices. These factors concern the different actors and the different stages in the food chain, that is producers and market regulations applied at this level (for example, withdrawals of fruit and vegetables because of quality standards), the food industry (in relation to issues such as supply chain management, packaging, safety rules and the recycling of wasted quantities), the retailing stage (where storage conditions and marketing are key parameters), and the final consumer (through the mechanisms which define her food consumption behavior). Secondary food losses could be reduced by increasing the use of products in human food, by using them for animal feed, and by recycling, especially for energy production.

\section{Improving the utilization of raw materials}

Priority should be given to the use of agricultural products for food. Extending and diversifying preservative processes can be used to delay the consumption of highly perishable products such as fruit and vegetables. Recycling technologies of co-products are efficient and well-developed. For example, the content of milk proteins can be fully utilized though traditional outlets like cheese and thanks to membrane technologies, the residual whey proteins can be simultaneously used as food additives in a very large range of products. It is not only a technological issue. In parallel, public policies should be developed for facilitating a reduction in losses and improving the food use of raw materials. Education of all actors in the food chain, from producers to final consumers, is a key parameter for the long term. It could be efficiently supplemented by shorter-term regulation on prices.

A large part of world crop production is used for animal feed. Farm and company animals also use an extensive variety of co-products from first- and secondtransformation of agricultural products, notably oilcakes (from oilseeds), corn gluten feed and corn germ meal (from corn). Using organic waste for feeding animals is also a promising solution that would allow a significant decline in the tension on arable lands.

\section{Developing new processes}

As the carbon circular economy develops, bio-refineries play a central role since they use plants and organic waste from both industrial and domestic processes [71]. Bio-refineries go beyond processes currently used in the food industry, as they include renewable energy and green chemistry to optimize whole plant use. Based on improvements in production and recycling technologies, they are promising tools to reduce food losses and waste through a reorganization and management of resource use and recycling, and an increased utilization of co-products. Perspectives offered by white and green biotechnologies are enlarging the range of utilization and valorization possibilities thanks to the degradation of lignocellulose and the development of new sources of oils, solvents or biomaterials.

\section{Understanding and changing domestic food practices}

According to Redlingshöfer and Soyeux [72], food losses and waste at home represent $42 \%$ of total secondary losses and waste in the European Union (89 million tons per year, i.e., $179 \mathrm{~kg}$ per person); the food industry is second (39\%, but includes by-products that are generally well-used), catering is third (14\%), and retailing is fourth (5\%). As a consequence, reducing food losses and waste at home is a potentially powerful lever. To achieve this objective and more generally to improve food 
management at home, a number of simple actions are available. For example, on her famous blog "No More Dirty Looks", Siobhan O'Connor presents ten ways to reduce the food that American households throw out, and what to do with it if it really is past its prime. ${ }^{g}$ Solutions include 'store food properly, 'make juice,' cook then freeze' but also 'find places that will make use of your waste' or 'shop like a Parisian'. h More generally, this list of intuitive recommendations shows that changing individual food practices is difficult as far as the food environment is concerned (for example, not everyone can shop like a Parisian!).

The use of food at home as well as the sociological representation of what food means may be very different from one country to another, even for those at the same level of economic development. It is also by changing the food environment, retailing and food industry practices, especially in terms of advertising, labeling, marketing or packaging, and influencing public policies and education that it will be possible to significantly reduce food losses and waste at home, and along the whole food chain. Efficiency requires combining a large variety of actions that involve all actors in the food chain.

Defining and adopting healthier and more sustainable diets 'Westernized' diets are unhealthy because of an excessive calorie intake and/or because they are unbalanced from a nutritional standpoint. Defining healthy and sustainable diets is a challenge. Defining the conditions allowing people to adopt them is even more difficult. As in the case of food losses and waste, there is no unique solution that could apply to all individuals and households in all countries. Combined actions that work simultaneously on demand and supply factors will be more efficient.

\section{Assessing the nutritional and environmental impacts of diets simultaneously}

Assessing the nutritional and environmental impacts of different diets is imperative. To that end, a research effort is required to develop methods aimed at assessing the nutritional value of food products and their integration in eating patterns. Related to that, research at a sufficiently detailed level is needed on the nutritional qualities of plant and animal products; for example, determining how to restrict the consumption of animal products without adversely affecting health. Research should also target methods for assessing the environmental impacts of diets. To a large extent, research work developed in that domain concerns carbon dioxide and greenhouse gas emissions. Such research should be extended to other environmental dimensions, notably by including the impact of diets on fossil energy, water and biodiversity. Furthermore, the definition of the carbon footprint of diets should take into account greenhouse gas emissions that are linked to direct and indirect landuse changes. Research efforts currently developed in that domain are mainly applied to biofuels; they could easily be extended to diets as well.

Such a research agenda implies a substantial effort in terms of methods and data which should be coordinated and harmonized at an international level. Existing databases should be shared and extended, notably by incorporating information from the private sector on processed food products.

\section{Reducing the quantities}

As previously noted, the challenge of reducing the intake quantity of over-nourished people is essential. It implies not only a modification of consumer habits but also a modification of the economic model of the supply chain because the main driver for supply chain development is currently an increase in quantities sold. Research is needed to develop new economic models of the supply chain, to assess the sustainability performances of these models, and to work out how they could be implemented.

\section{Better understanding of food consumption behaviors and their determinants to favor desirable changes}

There is no single diet that can be considered as nutritionally adequate. Several diets can achieve the same nutritional requirements in terms of energy and specific nutrients. Even if detailed information is largely lacking for the moment, these various diets, while adequate from a nutritional point of view, will very likely have differing impacts on the environment. But it is also likely that there is no unique diet that is preferable from both a nutritional and environmental standpoint when all the environmental dimensions are taken into account.

Combined actions on demand and supply factors Changing food consumption behaviors is a very difficult task as eating encompasses a large range of dimensions including historical, cultural, sociological and even emotional aspects. Changing food consumption behaviors requires simultaneously mobilizing the various levers identified earlier in this article through a combination of actions affecting both the demand and supply side. An increasing number of success stories in different countries confirm that it is through a combination of actions that it will be possible to efficiently and durably change food consumption behaviors. These actions should comprise both short-term objectives and long-term targets.

Enhancing food intake control Research in progress will allow better identification of the food properties such as nutrient content, texture, and sensorial properties that have an impact on satiety/satiation, an important 
biological event that controls food intake. Nevertheless, it is necessary to establish to what extent these are key effects for the control of body weight and composition. Furthermore, given the importance of the food consumption environment, it is crucial to act simultaneously on environmental factors to induce sustainable food-related behavioral changes. Research and experiments should be conducted to identify the best ways to act on these proximate environmental drivers. Public policy could then have an impact on public catering environments, especially on those disturbance factors such as noise and short eating times. Consistent information also should be provided concerning disturbance factors associated with the home, such as how watching television while eating affects consumption patterns.

Acting on (relative) prices on foods Modifying the relative prices of the different food products by taxing the 'bad' foods and subsidizing the 'good' ones is part of the solution, even if the distinction between what is a 'bad' versus a 'good' food is not simple, from both a nutritional and environmental point of view. It is very likely however that public policies that have either a direct or indirect impact on eating patterns, and more generally on food and agricultural systems, are insufficiently consistent. Thus, improving the consistency of public policies is a priority. This could be achieved by following two basic economic policy principles: first, by seeking a consensus (or at least a politically acceptable compromise) on policy objectives, taking into account priorities and trade-offs, and second, by targeting the objective at the source using a distinct instrument for each goal (following the so-called targeting principle). Furthermore, modifying the relative prices of the various foods would also influence supply by reducing the availability of more expensive goods (their prices should go up) and increasing the availability of less expensive goods (their prices should decrease).

Taking into account the specificities of individuals, social groups and countries The efficiency of economic instruments will be enhanced if these instruments are used in conjunction with other actions aimed at defining a better food environment and/or by modifying behavioral habits. To do this, policies must target individuals, their families and their social communities. As there are critical periods for changing eating patterns during the life span, such as childhood, marriage, child birth or aging, efficiency will be gained by targeting these periods and taking into account the characteristics and needs of the corresponding populations. More generally, as there is a range of consumer types in each country and consumption behavior varies during a consumer's life cycle, the research and policy agenda should address detailed knowledge of food consumption behaviors of individuals in relation to their position in the life cycle, their socioeconomic status and the food environment. This research agenda includes the importance of job-related physical activity in explaining weight gaps; gender differences in food consumption, behavior and weight; the role of the matching market, such as marriage or a birth, in determining behavior and weight; and, on a more global scale, the analysis of factors that contribute to maintaining differences in food consumption behavior between countries while other factors are maintained or controlled [73].

Acting on demand factors Action requires a better understanding of the multi-factorial relationship of consumers vis-à-vis their food, how this relationship evolves, and drivers of changes. Action should aim to inform consumers on the risks of following unhealthy diets, of being overweight and of being obese. Any action taken should try to influence food consumption behaviors through nutritional education, sensorial education (especially for children and teenagers), social marketing (because this technique can modify not only individual behaviors but also social norms ${ }^{\mathrm{i}}$ ) as well as through the use of understandable food labeling for nutritional and environmental purposes. Efficiency will be enhanced if all these actions are combined and shortterm measures are consistently included in a long-term action plan.

Acting on supply factors In a large majority of cases, acting solely on the demand side is not sufficient. It is equally important to intervene on the supply side, more specifically in the food industry, the retailing sector and the consumption environment. In that regard, many analysts suggest that the free market is not optimal (see, for example, [74-76]). Policy intervention is thus required and justified from a public economic point of view. Instruments that public authorities can use for that end are multiple, from simple interdictions to operations developed jointly with the food industry and the retailing actors. These should be encouraged as their efficiency is enhanced by the adhesion of actors to program objectives. The research and policy agenda should also address the issue of food marketing and its regulation (see, for example, [75]), and the question of the 'architecture' of food choices, that is the decrease in the availability and visibility of unhealthy foods and conversely, the increase in the availability and visibility of healthier options. This availability/visibility issue concerns shopping malls, fast-food restaurants, supermarkets, and all buying and consumption collective places such as schools, canteens and work places. Several success 
stories in that domain are well-documented (see, for example, [77-79]).

\section{Saving fossil energy and natural resources}

Reducing losses and waste along the food chain should permit the conservation of fossil energy and other natural resources. In general, increasing the sustainability of eating patterns and food systems requires a decrease in the use of fossil energy and natural resources, notably of water and land. Although the research needs and policy recommendations illustrated herein apply to energy, they extend to other natural resources such as water and land as well.

A recent report from the United States Department of Agriculture [80] summarizes the issue in the specific case of the United States, but the analysis extends to all countries with 'westernized' eating patterns and food systems. According to the authors, 'energy is used throughout the United States food supply chain, from the manufacture and application of agricultural inputs, such as fertilizers and irrigation, through crop and livestock production, processing, and packaging; distribution services, such as shipping and cold storage; the running of refrigeration, preparation, and disposal equipment in food retailing and foodservice establishments; and in home kitchens. Dependence on energy throughout the food chain raises concerns about the impact of high or volatile energy prices on the price of food, ${ }^{j}$ as well as about domestic food security and the Nation's reliance on imported energy. Use of energy in the food chain could also have environmental impacts, such as through carbon dioxide emissions.'

In the United Kingdom, the food system represents 13\% of total energy consumption. The details of the energy consumed in the food system are provided for all activities from field to fork (Figure 9). Transportation and logistics consume the highest amount of energy (30\%), followed by processing (17\%) and then catering (16\%). Figure 9 also highlights the small contribution of agriculture to energy consumption, with only $5 \%$, while food cooking at home represents $9 \%$. Similar information is provided for the United States in Figure 10. In that country, food activities at home come first with $31 \%$ and agriculture second with $22 \%$, a percentage much higher than in the United Kingdom. Differences in data, system boundaries, measurement methods and category definition (for example, one study includes all 'home activities' while the other considers only 'food cooking at home') can explain in part this difference between the situation in the United Kingdom and the situation in the United States. Furthermore, these percentages do not include the energy content of agricultural imports and exports that vary considerably between the two countries and can also explain some differences. More generally, this simple comparison suggests that the research agenda should address data and methodology needs to ensure that such breakdowns are robust and comparable. It should also address the detailed analysis of differences between countries and factors that could explain these discrepancies, especially with the aim of identifying and generalizing the best practices. Here also, a holistic approach is required.

Energy use in food transforming activities is of the same order of magnitude in both the United Kingdom (17\%) and the United States (16\%). Following the energy crisis of the 1970s, the food industry has developed and adopted new technologies to reduce its dependence on energy. Significant progress in the thermal processing of foods (multi-stage unit operations, energy recycling, notably by using co-products of the first-transformation process, replacement of non-thermal technologies) has been achieved. Less research effort has been devoted to home food activities and the energy yields of culinary cooking techniques are far from being optimized. As a result, a priority of the research agenda is the question of home food management, including an analysis of losses, waste and energy consumption in culinary processes. Transport and energy use for that purpose are also of importance, notably because of the increasing distance between production and consumption places, as well as the concentration of food retailing.

\section{Conclusions}

A change in eating patterns is a key condition for ensuring world food security. According to the Agrimonde foresight study [6], if daily food consumption per person keeps steadily increasing, it will reach $3,600 \mathrm{kcal}$ in 2050 and the world will have to produce no less than $62 \mathrm{G} \mathrm{kcal} \mathrm{for} \mathrm{feeding} \mathrm{nine} \mathrm{billion} \mathrm{people} \mathrm{at} \mathrm{that} \mathrm{date,}$ but if daily food consumption per person remains limited to $3,000 \mathrm{kcal}$ in 2050 , only $42 \mathrm{G} \mathrm{kcal} \mathrm{(32 \%} \mathrm{less)} \mathrm{will}$ need to be produced.

Acting on eating patterns, alone, however, is not sufficient because the food challenge requires actions on both the supply and demand side. On the agricultural production side, in addition to reducing post-harvest losses, it will be necessary to increase crop yields, especially in world regions where they are currently low, and it is necessary to do so in a sustainable way. In other words, agricultural practices and systems used worldwide should radically change $[6,70]$. On the food consumption side, a first priority is to reduce waste and losses at distribution and final consumption stages by improving the utilization of raw materials for food and feed, by developing new transformation processes based on the concept of bio-refineries, and by improving our understanding of food consumption behaviors in order to induce desirable changes and define adapted public regulations. It will be also necessary to change current diets that are excessive and/or 


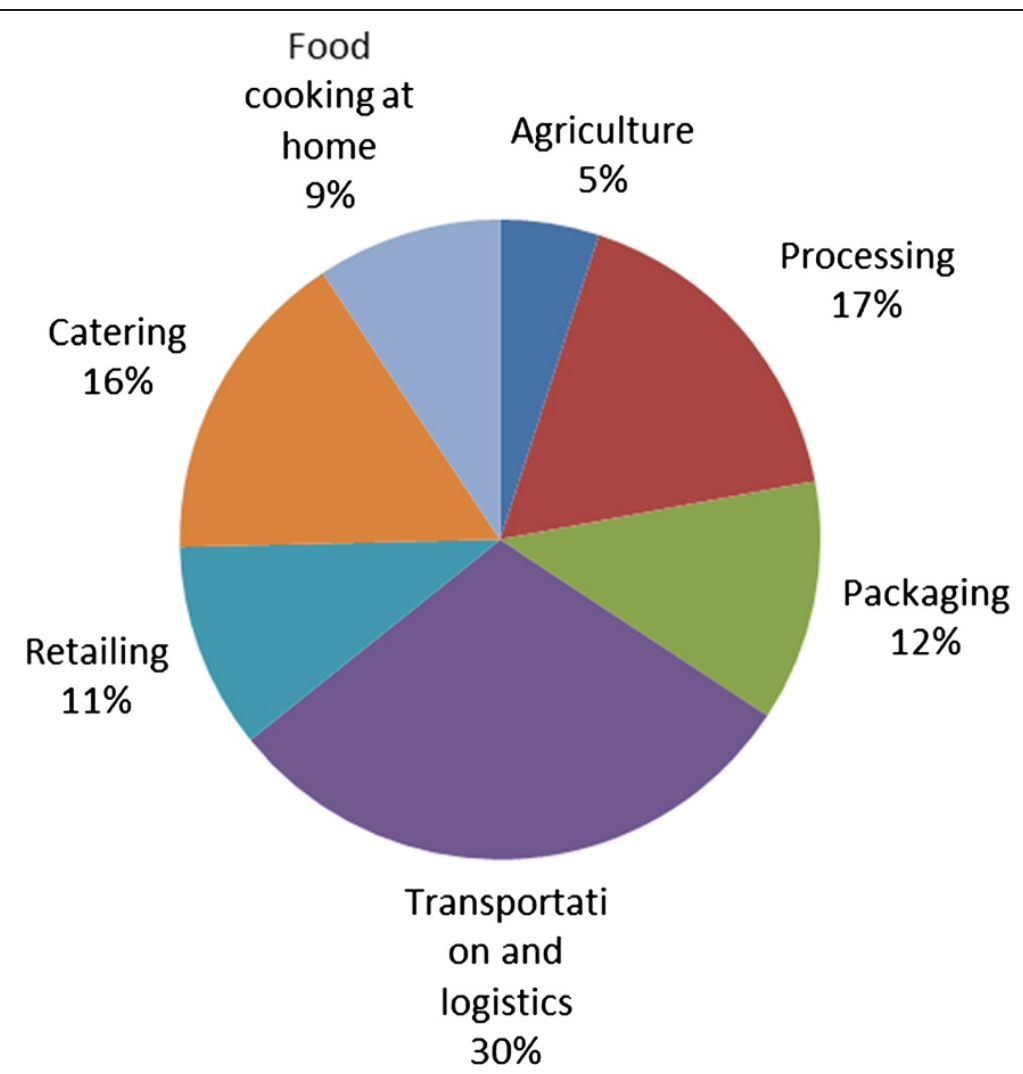

Figure 9 Breakdown of energy consumption of the United Kingdom food chain according to activities (2002) [81].

unbalanced and more generally, to reverse the global trend towards the 'westernization' of eating patterns worldwide as the latter presents numerous shortcomings and drawbacks, notably in terms of health, impacts on the environment and use of natural resources.
This does not mean setting up a common eating pattern for every part of mankind. Although eating patterns have tended to converge over the past decades, they remain diverse throughout the world and are determined by a complex set of physiological, economic, historical,

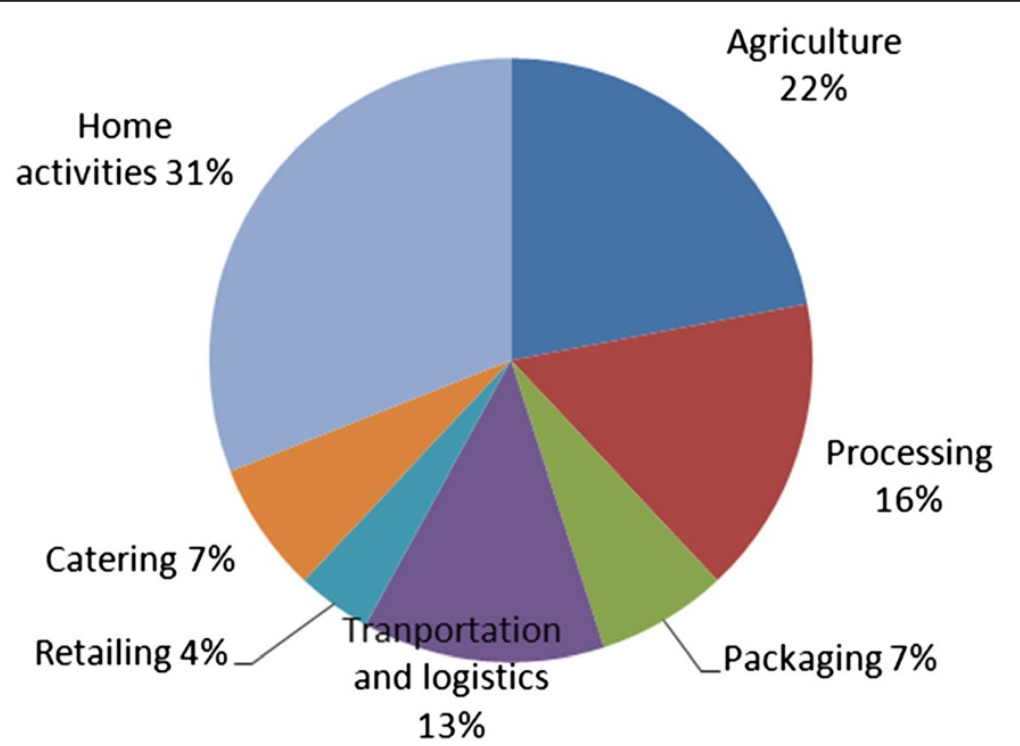

Figure 10 Breakdown of energy consumption of the United States food chain according to activities (2002) [82]. 
cultural and sociological factors. This diversity should be exploited further to define healthier and more sustainable diets.

To that end, a holistic approach is required. Reducing losses and waste along the whole food chain should result in significant savings of fossil energy and other natural resources, and those savings are a key condition to increasing the sustainability of both eating patterns and food systems. More generally, eating patterns and food systems could be sustainable only if they rely on a thrifty use of all non-renewable natural resources. It would be necessary to assess the nutritional and environmental impacts of alternative diets simultaneously in order to set the targets and identify the trade-offs. Research in this area should focus on data needs and the definition of robust methodologies. Far from being imposed, healthier and more sustainable diets must be based on changes accepted by everyone. This requires a better understanding of food consumption behaviors and of their various determinants in order to favor desirable changes through actions and regulations on buying and consumption behaviors, the food environments, the relative prices of foodstuffs as well as the behavior of the food and retailing industry. These actions and regulations will have to take into consideration the specificities of individuals, social groups and countries. ${ }^{k}$

Many actions need to be taken to ensure food security throughout the world. And many of those actions have something to do with eating patterns. In other words, future food security cannot be achieved unless food patterns have been identified and modified. Here is food... for thought!

\section{Endnotes}

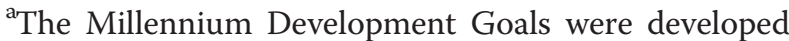
out of the eight chapters of the Millennium Declaration signed in September 2000. There are eight goals with twenty-one targets and a series of indicators for each target: eradicate extreme poverty and hunger (with target 1A: halve the proportion of people who suffer from hunger); achieve universal primary education; promote gender equality and empower women; reduce child mortality rate; improve maternal health; combat HIV/AIDS, malaria and other diseases; ensure environmental sustainability; and develop a global partnership for development. For more details, see [83].

${ }^{\mathrm{b}}$ This estimate sums up emissions of the livestock commodity chain at the various production stages. The production stages include deforestation for pasture and feed crops, animal production, and the processing and transportation of animal products.

${ }^{\mathrm{c}}$ For example, in the United States, $2.6 \mathrm{~kg}$ of feed are needed to produce $1 \mathrm{~kg}$ of chicken, but $7 \mathrm{~kg}$ of feed are needed to produce $1 \mathrm{~kg}$ of beef. [84].
${ }^{d}$ See [85] on the consequences of urbanization for food and farming.

[29] analyzes the nutrition transition and its health consequences in the specific case of India.

${ }^{\mathrm{f}}$ Title of their article published in 2010 in the Journal of Nutrition.

ghttp://www.good.is/post/10-ways-to-reduce-foodwaste-at-home/.

${ }^{\mathrm{h}}$ This means having only the basics at home and going to the neighborhood grocery store before supper.

${ }^{\mathrm{i}}$ See [86] and [87].

${ }^{j}$ On the relationship between crude oil and agricultural/food prices, and the impact of this relation on agricultural and food price volatility, see [88].

${ }^{\mathrm{k}}$ In that perspective, we recommend the special issue of Public Health Nutrition [89] on the Mediterranean diet, which is presented and analyzed as an example of a sustainable diet in which nutrition, biodiversity, local food production, culture and sustainability are strongly interconnected.

\section{Competing interests}

The authors declare that they have no competing interests.

\section{Authors' contributions}

HG led the study, reviewed background literature, structured the concepts, developed the arguments and wrote most of the manuscript. BDV, CE, MM, $M R$ and MG reviewed background literature, developed important concepts, helped design the arguments and wrote parts of the manuscript. All authors read and approved the final manuscript.

\section{Authors' information}

$\mathrm{HG}$ is director of research and scientific director in charge of agriculture at INRA with expertise in economics, agricultural market modeling and agricultural policy analysis as well as in research management. BDV is director of research and deputy head of the 'nutrition, chemical food safety and consumer behavior' research division at INRA with expertise in nutrition and research management. CE is deputy scientific director in charge of food and nutrition at INRA with expertise in nutrition, sustainable food systems and research management. MM is professor and president of the INRA research centre of Toulouse, with experience in food process engineering and research management. MR is a scientific project manager at INRA with an academic background in food history and food science, a doctorate in the historical archaeology of these topics, and experience in research management. MG is CEO of INRA with expertise in physico-chemistry of biotransformations and great experience in public policy and research management.

\section{Acknowledgements}

This review was funded by INRA and conducted in support of the Commission on Climate Change, Sustainable Agriculture and Food Security which was convened by the CGIAR Research Program on Climate Change, Agriculture and Food Security (http://ccafs.cgiar.org/commission). We thank all the participants of the Bellagio workshop (5-9 September 2011), especially Christine Negra and Sonja Vermeulen, where an earlier draft of this paper was discussed. We also thank Antoine Momot, John Kearney and two anonymous referees for very helpful comments.

\section{Author details}

${ }^{1}$ INRA Paris, 147 rue de l'université, 75 338, Paris Cedex 07 France. ${ }^{2}$ INRA Toulouse, 24 Chemin de Borde Rouge, CS 52627, 31326 Castanet Tolosan, Cedex, France.

Received: 24 March 2012 Accepted: 10 July 2012

Published: 3 September 2012 
References

1. FAO: Rome Declaration on World Food Security and World Food Summit Plan of Action. Rome: World Food Summit; 1996.

2. Nations U: Report of the World Food Conference: 1974 November 5-16; New York. Rome: United Nations; 1974.

3. FA0: The State of Food Insecurity in the World. Rome: Addressing Food Insecurity in Protracted Crises; 2010

4. Childhood and Maternal Undernutrition. http://www.who.int/publications/ $\mathrm{cra} /$ chapters/volume1/part2/en/index.html.

5. WHO: Obesity and Overweight. Fact Sheet No 311. Geneva 2011

6. Paillard S, Treyer S, Dorin B: Agrimonde, Scenarios and Challenges for Feeding the World in 2050. Paris: Quae; 2010

7. FAO, IFAD, WFP: Reducing Poverty and Hunger: the Critical Role of Financing for Food, Agriculture and Rural Development. Rome: Paper prepared for the International Conference on Financing for Development. Monterrey, Mexico; 2002. http://www.ifad.org/events/monterrey/e/jointe.pdf.

8. IFAD: IFAD Strategic Framework 2011-2015. Rome: IFAD; 2011. http://www. ifad.org/sf/strategic_e.pdf.

9. Combris P: Le poids des contraintes économiques dans les choix alimentaires. Cahiers de Nut et de Diététique 2006, 41:279-284.

10. Popkin BM: Global nutrition dynamics: the world is shifting rapidly toward a diet linked with non-communicable diseases. Am J Clin Nutr 2006, 84:289-298.

11. Combris P, Maire B, Réquillart V: Consommation et consommateurs. In DuAlIne -durabilité de l'alimentation face à de nouveaux enjeux: Questions à la recherche. Edited by Esnouf C, Russel M, Bricas N. Paris: Quae; 2011:26-43.

12. Etiévant $\mathrm{P}$, Bellisle F, Dallongeville J, Etilé F, Guichard E, Padilla M, RomonRousseaux M: Les comportements alimentaires. Quels en sont les déterminants ? Quelles actions, pour quels effets? Paris: INRA, Expertise Scientifique Collective; 2010.

13. Kearney J: Food consumption trends and drivers. Phil Trans Royal Soc $B$ 2010, 365:2793-2807.

14. Swinburn BA, Caterson I, Seidell JC, James WPT: Diet, nutrition and the prevention of excess weight gain and obesity. Public Health Nutr 2004 7(1A):123-146

15. Reardon T, Swinnen J: Agrifood sector liberalisation and the rise of supermarkets in former state-controlled economies: a comparative overview. Dev Pol Rev 2004, 22:515-523.

16. Reardon $\mathrm{T}$, Timmer CP, Barrett CB, Berdegué J: The rise in supermarkets in Africa, Asia and Latin America. Am J Agric Econ 2003, 85:1140-1146.

17. Smil V: Feeding the World. A Challenge for the Twenty-First Century. Cambridge: MIT Press; 2000

18. Lundqvist J, de Fraiture C, Molden D: Saving water: from field to fork-curbing losses and wastage in the food chain. SIWI Policy Brief. Stockholm: SIWl; 2008.

19. Dubuisson-Quellier S: Consumer involvement in fair trade and local food systems: delegation and empowerment regimes. GeoJournal 2008, 73:55-65.

20. Dubuisson-Quellier S: From consumerism to the empowerment of consumers: the case of consumer oriented movements in France. Sustainability 2010, 2:1849-1868.

21. Colleu S, Guyomard H, Soler LG: Les consommateurs à la recherche d'une réidentification et d'une réappropriation de leur alimentation. Paris: INRA; 2010.

22. Soler LG, Réquillart $V$, Trystram G: Organisation industrielle et durabilité. In DuALIne-durabilité de l'alimentation face à de nouveaux enjeux: Questions à la recherche. Edited by Esnouf C, Russel M, Bricas N. Paris: Quae; 2011:85-95.

23. European Commission: Sustainable Food Consumption and Production in a Resource-Constrained World. Third SCAR (Standing Committee on Agricultural Research). Brussels: European Commission; 2011.

24. Firbank L, Petit S, Smart S, Blain A, Fuller R: Assessing the impacts of agricultural intensification on biodiversity. Phil Trans Royal Soc 2008, 363:777-787.

25. Jenkins M: Science. Prospects for biodivers 2003, 302:1175-1177.

26. Chamberlain DE, Fuller RJ, Bunce RGH, Duckworth JC, Shrubb M: Changes in the abundance of farmland birds in relation to the timing of agricultural intensification in England and Wales. J Appl Ecol 2000 37:771-788.

27. FAO: Livestock's Long Shadow: Environmental Issues and Options. Rome: FAO; 1996.

28. IPCC: Fourth Assessment Report: Climate Change. 2007. http://www.ipcc.ch/ publications_and_data/publications_and_data_reports.shtml.
29. Shetty P: Nutrition transition in India. Public Health Nutr 2002, 5:175-182.

30. Technical Report Series WHO: Diet, Nutrition and the Prevention of Chronic Diseases. Geneva: WHO; 2003:2003.

31. Popkin BM: Will china's nutrition transition overwhelm its health care system and slow economic growth? Health Aff 2008, 27:1064-1076.

32. Etilé F: Food consumption and health. In Oxford Handbook of the Economics of Food and Agricultural Policy. Edited by Lusk J, Roosen J, Shogren J. Oxford, UK: Oxford University Press; 2011:317-346.

33. Visscher TLS, Seidell JC: The public health impact of obesity. Annu Rev Public Health 2001, 22:355-375.

34. Finkelstein EA, Strombotne KL, Popkin BM: The costs of obesity and the implications for policymakers. Choices 3rd quarter 2010, 25(3).

35. Stehfest E, Bouwman L, Vuuren DPV, Elzen MGJD, Eichout B, Kabat P. Climate benefits of changing diet. Clim Chang 2009, 95:83-102.

36. Darmon N, Soler LG: Impact carbone et qualité nutritionnelle des choix alimentaires: une étude de cas. In DuALIne-durabilité de l'alimentation face à de nouveaux enjeux: Questions à la recherche. Edited by Esnouf C, Russel M Bricas N. Paris: Quae; 2011:44-58.

37. Vieux F, Soler LG, Supkova M, Russel M, Redlingshöfer B, Darmon N: Is there a relation between the nutritional adequacy of diets and their greenhouse gas emissions? A study based on self-selected French diets. Paris: INRA; 2011.

38. Vieux F, Darmon N, Touazi D, Soler LG: Food consumption and greenhouse gas emissions: changing food consumption patterns or consuming less? Paris: INRA; 2011.

39. Woods SC, D'Alessio DA: Central control of body weight and appetite. J Clin Endocrinol Metab 2008, Suppl 1:37-50.

40. Berthoud HR: Interactions between the « cognitive » and « metabolic » brain in the control of food intake. Physiol Behav 2007, 91:486-498.

41. Cowley MA, Smith RG, Diano S, Tschop M, Pronchuk N, Grove KL, Strasburger CJ, Bidlingmaier M, Esterman M, Heiman ML, Garcia-Segura LM, Nillni EA, Mendez P, Low MJ, Sotonyi P, Friedman JM, Liu H, Pinto S, Colmers WF, Cone RD, Horvath TL: The distribution and mechanism of action of ghrelin in the CNS demonstrates a novel hypothalamic circuit regulating energy homeostasis. Neuron 2003, 37:649-661.

42. Birch LL, Deysher M: Caloric compensation and sensory specific satiety: evidence for self-regulation of food intake by young children. Appetite 1986, 7:323-331

43. Blundell JE, Lawton CL, Hill AJ: Mechanisms of appetite control and their abnormalities in obese patients. Horm Res 1993, Suppl 3:72-76.

44. Bellisle F, Dalix AM, Airinei G, Herberg S, Peneau S: Influence of dietary restraint and environmental factors on meal size in normal-weight women: a laboratory study. Appetite 2009, 53:309-13.

45. Rogers PJ: Eating habits and appetite control: a psychobiological perspective. Proc Nutr Soc 1999, 58:59-67.

46. Alston JM, Pardey PG: Theme overview: agricultural productivity and global food Security in the long run. Choices 4th quarter 2009, 24(4). http://www.choicesmagazine.org/magazine/article.php?article $=90$.

47. Beydoun MA, Powell LM, Chen X, Wang Y: Food prices are associated with dietary quality, fast food consumption, and body mass index among U.S. children and adolescents. J Nutr 2010, doi:10.3945/jn.110.132613.

48. Schaffer H, Hunt DB, Ray DE: US agricultural commodity policy and its relationships to obesity, Background Paper developed for the Wingspread Conference on Childhood Obesity, Healthy Eating and Agriculture Policy, Racine. Wisconsin: United States; 2007

49. Schnoover H, Muller M: Food without thought: how US farm policy contributes to obesity. Minneapolis: Institute for Agriculture and Trade Policy; 2006

50. Lloyd-Williams F, O'Flaherty M, Mwatsama M, Birt C, Ireland R, Capewell S: Estimating the cardiovascular mortality burden attributable to the Common Agricultural Policy on dietary satured fats. Bull World Health Org 2008, 86:535-542.

51. Mazzochi M, Traill WB, Shogren JF: Fat Economics: Nutrition. Oxford: Oxford University Press; 2009.

52. Alston JM, Rickard BJ, Okrent AM: Farm policy and obesity in the United States. Choices 3rd quarter 2010, 25(3). http://www.choicesmagazine.org/ magazine/pdf/block 51.pdf.

53. Bonnet $C$, Réquillart $\mathrm{V}$ : Does the EU sugar policy reform increase added sugar consumption? An empirical evidence on the soft drink market. Health Econ 2011, 20:1012-1024.

54. Périssé J, Sizaret $F$, François $P$ : Effet du revenu sur la structure de la ration 
alimentaire. FAO, Bull Nutr 1969, 7(3):1-10

55. Marmot M: Income inequality, social environment, and inequalities in health. J Policy Anal Manage 2001, 20:56-159.

56. Hawkins SS, Cole T, Law C: Maternal employment and early childhood overweight: findings from the UK millennium cohort study. Int J Obes 2008, 32:30-38.

57. Popkin BM, Duffey K, Gordon-Larsen P: Environmental influences on food choice, physical activity and energy balance. Physiol Behav 2005, 86: 603-613.

58. Inagami S, Cohen DA, Brown A, Asch M: Body mass index, neighbourhood fast food and restaurant concentration, and car ownership. J Urban Health 2009, 86:683-695.

59. Hawkes $C$ : The role of foreign direct investment in the nutrition transition. Public Health Nutr 2005, 8:357-365.

60. Willett W: Eat, drink and be healthy: the Harvard medical school guide to healthy eating. New York: Free Press; 2002.

61. Volatier JL: Le repas traditionnel se porte encore bien. Consommation \& Modes de Vie 1999, 132:1-4

62. Chauffaut D: L'évolution des relations entre générations dans un contexte de mutation du cycle de vie. Paris: CREDOC; 2001:163.

63. Guignon N, Collet M, Gonzales L, de Saint Pol T, Guthmann JP, Fonteneau L: La santé des enfants en grande section de maternelle en 2005-2006. Etudes \& Résultats 2010, 737:1-8.

64. Mackenbach JP, Stirbu I, Roskam AJR, Schaap MM, Menvielle G, Leinsalu M, Kunst AE: Socioeconomic inequalities in health in 22 European countries. N Engl J Med 2008, 358:2468-2481.

65. Charles MA, Eschwege E, Basdevant A: Monitoring the obesity epidemic in France: the Obepi surveys 1997-2006. Obesity 2008, 16:2182-2186.

66. Leclerc A, Chastang JF, Menvielle G, Luce D: Socioeconomic inequalities in premature mortality in France: have they widened in recent decades? Soc Sci Med 2006, 62:2035-2045.

67. Caillavet F, Lecogne C, Nichèle V: La consommation alimentaire: des inégalités persistantes mais qui se réduisent. In Cinquante Ans de Consommation en France. Paris: INSEE; 2009:49-62.

68. Recours F, Hébel P: Les populations modestes ont-elles une alimentation déséquilibrée? Paris: CREDOC; 2006.

69. Regnier F: Obésité, goûts et consommation: intégration des normes d'alimentation et appartenance sociale. Rev Fr Soc 2009, 50:747-773.

70. The Government Office for Science, London: Foresight. The Future of Food and Farming (2011). London: Final Project Report; 2011.

71. Colonna P, Fournier S, Touzard JM: Systèmes alimentaires. In DuALIne -durabilité de l'alimentation face à de nouveaux enjeux: Questions à la recherche. Edited by Esnouf C, Russel M, Bricas N. Paris: Quae; 2011:59-84.

72. Redlingshöfer B, Soyeux A: Pertes et gaspillages: les connaître et les reconnaître pour les réduire et les valoriser. In DuALIne-durabilité de l'alimentation face à de nouveaux enjeux: Questions à la recherche. Edited by Esnouf C, Russel M, Bricas N. Paris: Quae; 2011:112-129.

73. Philipson T: The world-wide growth in obesity: an economic research agenda. Health Econ 2001, 10:1-7.

74. Hawkes C: Regulating and litigating in the public interest: regulating food marketing to young people worldwide -trends and policy drivers. Am J Public Health 2007, 97:1962-1973.

75. Harris JL, Pomeranz JL, Lobstein T, Brownell KD: A crisis in the marketplace: how food marketing contributes to childhood obesity and what can be done. Annu Rev Public Health 2009, 30:211-225.

76. Stanley F, Daube M: Should industry care for children? Public health advocacy and law in Australia. Public Health 2009, 123:283-286.

77. Seymour JD, Yaroch AL, Serdula M, Blanck HM, Khan LK: Impact of nutrition environmental interventions on point-of-purchase behavior in adults: a review. Prev Med 2004, Suppl 2:108-136.

78. Knai C, Pomerleau J, Lock K, McKnee M: Getting children to eat more fruit and vegetables: a systematic review. Prev Med 2006, 42:85-95.

79. Lawrence $S$, Peterken $R$, Burns C: Fresh kids: the efficacy of a health promoting schools approach to increasing consumption of fruit and water in Australia. Health Promot Int 2007, 22:218-226.

80. Canning P, Charles A, Huang S, Polenske KR, Waters A: Energy use in the US food system. Washington DC: USDA-ERS; 2010

81. Smith A, Watkiss P, Tweddle G, McKinnon A, Browne M, Hunt A, Treleven C, Nash C, Cross S: The validity of food miles as an indicator of sustainable development: Food Miles Final Report. London: DEFRA; 2005.
82. Heller MC, Keoleian GA: Life cycle-based sustainability indicators for assessment of the US food system, Report CSS00-94 of the Center for Sustainable Systems. Ann Arbor 2000,

83. We Can End Poverty: Millennium Development Goals. A Gateway to the UN System's Work on the MDGs. 2015. http://www.un.org/millenniumgoals/bkgd. shtml.

84. Leibtag E: Corn prices near record high, but what about food costs? Amber Waves 2008, 6:10-15.

85. Satterthwaite D, McGranahan G, Tacoli C: Urbanization and its implications for food and farming. Phil Trans Royal Soc B-Biological Sciences 2010, 365:2809-2820.

86. Kotler P, Armstrong G: Principles of Marketing. New Jersey: Prentice Hall International; 2005

87. Henley N, Raffin S: EPODE (Ensemble, Prévenons l'Obésité des Enfants or Together, Let's Prevent Childhood Obesity') case study: preventing childhood obesity. J Mark Manage, in press.

88. Hajkowicz S, Negra C, Barnett P, Clark M, Harch B, Keating B: Food price volatility and hunger alleviation - can Cannes work? Agric Food Secur 2012, 1:8. doi:10.1186/2048-7010-1-8

89. Selected Conference Proceedings of the VIIIth Barcelona: International Congress on the Mediterranean Diet, Barcelona, Spain, 24-25 March 2010. Public Health Nutr 2011, 14(Suppl 12A):2271-2349.

doi:10.1186/2048-7010-1-13

Cite this article as: Guyomard et al.: Eating patterns and food systems: critical knowledge requirements for policy design and implementation. Agriculture \& Food Security 2012 1:13

\section{Submit your next manuscript to BioMed Central and take full advantage of:}

- Convenient online submission

- Thorough peer review

- No space constraints or color figure charges

- Immediate publication on acceptance

- Inclusion in PubMed, CAS, Scopus and Google Scholar

- Research which is freely available for redistribution 